\title{
INDICATIONS OF WINDOW DRESSING ON COMMERCIAL BANKS IN INDONESIA
}

\author{
Muchlis
}

\begin{abstract}
More than often, banks are ranked based on their total assets. The bigger its assets the higher its position in the rank. To maintain its position in a higher rank, a bank may take extra efforts, to maintain its total assets high, whether by increasing its performance or manipulating their financial statement like window dressing. The higher its position in the rank the more likely a bank to perform temporary banking activities at the year end to increase its assets. The examples of the such activities are increasing temporarily customer deposits in the year end. Those temporary activities in are tending toward a window dressing.

This paper examines the possibilities of window dressing activities at the year end conducted by high ranked banks by temporarily pushed their assets up through extra efforts in gathering temporary customer deposits at the year end. If those window dressing activities really exist, researchers expect that data will show temporary increase in assets, customer deposits and also cost of funds of high ranked banks in Indonesia. Researcher uses the monthly data and started from January 2006 untill December 2011.

This research shows an evidence that bank total assets increase significantly at the year-end and the increase is temporary. Further, the increase in total assets appears to be funded with purchased demand deposit, savings, and time deposits. This research also shows that larger banks are more likely than smaller banks to exhibit window dressing.
\end{abstract}

Keywords: banks, window dressing, asset.

\section{INTRODUCTION}

In banking industry, it is a common to judge an improvement of a bank performance by its improvement in the rank position of total assets. Every year, the central bank ranks the banks by their total assets. Also, prominent banking magazine like Infobank, every year announces the big ten of banks based on total assets. Seeing the importance of asset value, then the bank will continue to maintain the value of its assets from year to year. Bank can do many things to maintain its total assets, includes by conducting engineering on financial statements or by doing window dressing. Based on several conversations with some bankers, the researcher infers that many bankers get pressures to conserve their total assets at the year ends and take special efforts to avoid their assets going down. This research is triggered by the researcher's interests to prove the conjecture.

The researcher assumes that, large banks, especially those includes in big ten group in total assets, tend to have bigger motivation to maitain their position in the rank than those out of the big ten group. To maintain the position, the big banks may collect temporary public funds, such as demand, saving and time deposits at the year-end. These activities tend to 
be window dressing activities because the asset is increased only for a temporary achieving the total asset position in the year end balance sheet. After the year end passes, it is assumed that the total assets are allowed to go down deliberately.

Yang and Saffer (2009) at the begining of their paper said that, banks have more opportunities and incentives to perform window dressing, compared to other kind of firms. Banks can inrease their total assets temporarily at the year end by making temporary loans from the Central Bank and invest the fund in securities, to increase the bank total assets at the year end balance sheet. The motivation for doing such a window dressing activity may be to maintain a certain position in the totals asset based rank of banks. High position in the rank may caused the bank better exposed in publicity, that may put the bank in a better position in fund gathering competitions.

Previously, Allen and Sauders (1992) have detected window dressing in banking industry by showing that end-of quarter figures of bank total assets tend to be higher than quarterly average figures. This research applied Allan and Sauders methods to detect window dressing in Indonesian banking industry in the year-end balance sheets. In Indonesia, one of the sources of bank financing to increase the bank's assets is a third-party fund (Dana Pihak Ketiga or DPK). "Third party funds (DPK) obtained from collecting funds from surplus units that transfer the surplus funds as an element of funding for banks" (Ali, 2004). Third party funds (DPK) consists of demand deposits, savings and time deposits. Therefore, there are two difference in this research copared to Allan and Saunders (1992) as well as Yang and Saffer (2009). First, this research focused on year-end total assets figure, instead of quarter end figure, because it is assumed that the window dressing activities are conducted by big-ten banks to maitain their position in the total asset based rank of banks. Second, this research tried to detect to he possibility of banks using the third party fund in increase their assets temporarily, instead of other sources of fund such as purchased fund from interbank money markets.

This research also followed a theory mentioned by Yang and Saffer (2009) that larger banks are more likely to exhibit upward window dressing in total assets. As explained earlier, this is because larger banks have more motivation to keep their high position the total assets based rank of banks.

\section{HYPOTESIS DEVELOPMENT}

Positive accounting theory (PAT) is part of positive theory that attempts to make predictions of real world events. (Scott, 2009). In a certain situation, PAT tries to predict manager's choice of accounting policies, either to achieve efficient contracts for their companies or to maximize heir own interests. If their choices are based on company's interests in achieving efficient contracts then the manager's actions are called efficient contracting, but if their choices are to achieve their own interests then their actions are called opportunistic behavior. A lot of researches are conducted based on hypothesis that are developed based on positive accounting theory.

Mian and Smith (1990) assumed that managers chosed to consolidate a subsidiary if there are interdependence between parent and the subsidiary, so that managers can evaluate the performance of two companies as joint results. Therefore, Mian and Smith developed a hypothesis that if consolidated financial statements are prepared for internal 
monitoring of manager performance, it is less costly to also prepare consolidated statements for external reporting. (Scott, 2009). Mian and Smith's research is based on efficient contracting hypothesis of positive accounting theory.

Jones (1991) presumed that managers of firms that would benefit from import relief attempt to decrease earnings through earnings management during import relief investigations by the US International Trade Commission (ITC). Jones argues that decrease earnings would decrease the manager's bonus for the year of investigation, but the managers would accept the bonus decrease in order to get more benefit from protections from foreign competitors due to import relief granted by the government. Jones also predicted that after the year of investigation, the managers of would reverse the income so that the decreasing bonus previously sacrificed would be regained.

Mian and Smith (1990) and Jones (1991) assumed that managers would achieve their intentions, either to get efficient contracts for the companies or to maximize their own interests, by choosing accounting policies and not by conducting real activities in business operations. Roychowdhury (2006) found evidence that managers manipulating real activities to avoid reporting annual losses. The real activities like suggesting price discounts to temporarily increase sales, overproduction to report lower cost of goods sold. and discretionary expenditures to imporove reported margins. Roychowdhury suspected that firms reporting small or close to zero annual profits are those who tried to avoid reporting annual losses by conducted various real activities earnings management.

Like the above research, the hypothesis for this research is also developed based on positive accounting theory. Based on Allen and Sauders (1992) finding that there is an indication of end of quarter window dressing in total assets, in this research it is presumed tha there is end of year window dressing in total assets. Therefore, the first hypothesis proposed for this research is:

$\mathbf{H}_{1}$ : In the suspect banks, the increment of the assets on December is significantly larger than the monthly average of assets increment during the year.

Yang and Saffer (2009) findings showed that larger banks are more likely to exhibit upward window dressing in total assets. Therefore, in this research the suspect banks are presumed to be the banks the first five banks in the top ten of biggest banks. It assumed that the top five banks in this country will have strong motivation to maintain their position in the ranks. Due to strong motivation that they have to increase their assets, it is presumed that the big five banks will conduct special efforts in accumulating sources of funds at the year end. Therefore, the second hypothesis proposed in this research is:

$\mathbf{H}_{2}$ : In the top five banks, the increment of source of fund on December is significantly greater than the monthly average of source of fund during the year.

Being the top five banks will have some advantage in fund raising competition during the next year, so that the top five banks will be ready to pay higher cost of fund (COF) to 
gather more funds at the year end. Therefore, the third hypothesis proposed in this research is:

$\mathbf{H}_{3}$ : The increment of COF on December is significantly higher than the monthly average of COF during the year.

It is presumed that the year end increment of total assets is temporary for window dressing purposes., so that at the begining of the next year total assets would reverse automatically. Therefore, the fourth hypothesis proposed is:

$\mathrm{H}_{4}$ : At the begining of the years, the increment of total assets of the big five banks is significantly negative.

\subsection{Conceptual Framework}

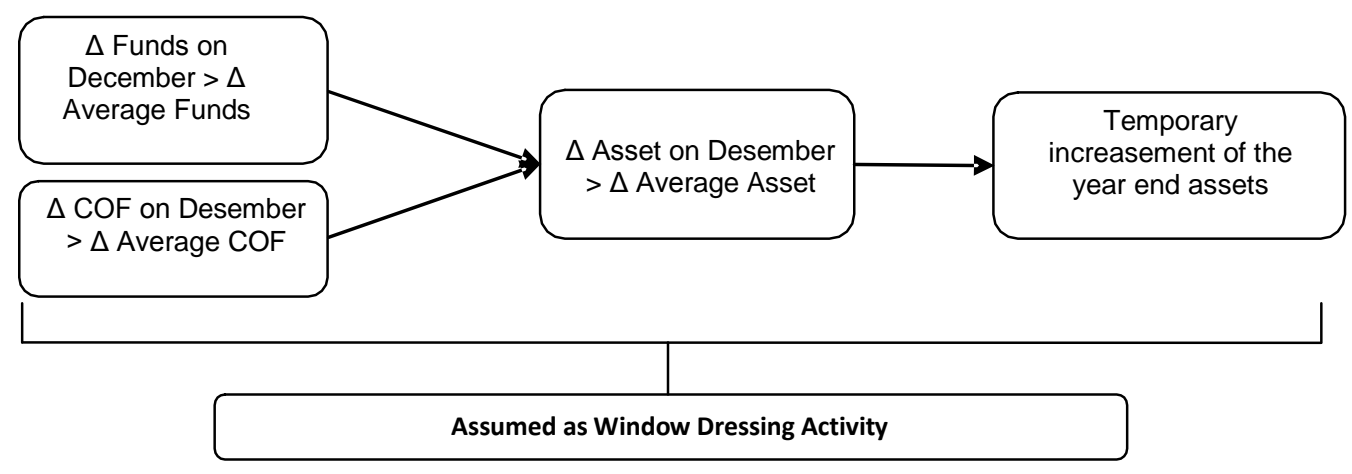

Picture 2.1 Conceptual Framework

This observation started with an assumption that the increment of funds in December is significantly higher than the average fund increment in the other eleven months. The increment of funds is presumed to a special effort to keep the assets high at the year end. The suspect banks are assumed to be ready to pay higher cost of funds (COF) in December compared to the average COF in the other eleven months. It is assumed that the December increment is only temporary so that in the begining of the next year there will be significant decrement in funds as well as assets of the suspect banks. Therefore, it assumed that the year end increment of assets is due to window dressing activities.

\section{RESEARCH METHODS}

\subsection{Sample and Population}

This study is focused on the five biggest banks. That is the fist half of the big ten banks in Indonesia. As a control sampel the researcher chooses randomly five sample banks from total population of about 110 banks in the country. The researcher presumed that the big five banks have high motivation to dress their window by temporarily increase their assets, while the control sample banks do not have such high motivations to do so.

All data is secondary data from literature and financial reports of each banks for the period of 2006 through 2011). 
Indications of ...

\subsection{Object of The Research}

The five biggest banks and the five randomly chosen control sample banks become the object of this research. The names of the ten banks are listed ini the table below.

Table 3.1 Research Samples

\begin{tabular}{|l|l|l|l|}
\hline No. & Bank & No. & Bank \\
\hline 1 & PT Bank Mandiri Tbk & 6 & PT Bank Commonwealth \\
\hline 2 & PT BRI Tbk & 7 & PT BPD Jabar Banten \\
\hline 3 & PT Bank Central Asia Tbk & 8 & PT Bank Mega Tbk \\
\hline 4 & PT BNI Tbk & 9 & PT Bank OCBC NISP Tbk \\
\hline 5 & PT CIMB Niaga Tbk & 10 & PT Bank National Nobu \\
\hline
\end{tabular}

Source: treated data

\subsection{Data Collection and Analysis Method}

The data of total assets and deposits are taken from banks balance sheets while the interest costs are obtained frim banks income statements, all of those are published in the website of Bank Indonesia (http://www.bi.go.id).

All the data are analyzed through descriptive as well as inferential statistic method. On descriptive statistic, data are analyzed with one-tail t test to prove the existence of assets increment at the year ends. Whereas using inferential method, data are analyzed with twotailed comparison t test, to show whether there is difference between the increment of assets at the year ends and those of other eleven month increments.

\section{DATA AND ANALYSIS}

\subsection{Descriptive Statistic Analysis}

Descriptive statistic analysis shows the average changes of assets, demand deposits (DD), saving deposits (SD), and time deposit (TD), and customer funds or DPK = (DD + SD + TD) and cost of funds (COF). It describes the changes at the year ends as well as the average changes at the other eleven months for the ten banks during the periode of six years from 2006 to 2011 . 
Table 4.1 Result of Descriptive Statistics

\begin{tabular}{|l|l|l|l|l|l|} 
Average changes of assets & 60 & -207080 & 21210430 & 1583160,87 & 2931969,498 \\
Average changes DD & 60 & -1053407 & 1691539 & 218683,20 & 487258,661 \\
Average changes of SD & 60 & -80495 & 2118174 & 471046,84 & 568320,661 \\
Average changes of TD & 60 & -865027 & 2692364 & 395759,57 & 710213,251 \\
Average changes of DPK & 60 & -548014 & 4054323 & 1085489,62 & 1214539,452 \\
Average changes of COF & 60 &, 0005871 &, 0080636 &, 004534532 &, 0016050133 \\
Changes of assets Nov-Dec & 60 & -2808428 & 62121122 & 8169263,17 & 12512348,211 \\
Canges of DD Nov-Dec & 60 & -6267801 & 38230244 & 2659625,18 & 6453908,294 \\
Changes of SD Nov-Dec & 60 & -66370 & 15760124 & 3149904,42 & 4211326,143 \\
Change of TD Nov-Dec & 60 & -7324289 & 14098194 & 1752243,03 & 3764319,583 \\
Changes of DPK Nov-Dec & 60 & -570503 & 62201847 & 7561772,63 & 12220057,113 \\
Changes of COF Nov-Dec & 60 &,- 0038834 &, 0614971 &, 004233101 &, 0089118677 \\
Valid N (listwise) & 60 & & & & \\
\hline
\end{tabular}

Notes:

Assets, DD, SD, TD = in million Rupiah

Cost of Fund $=$ as percentage

Source: Processed secondary data

Table 4.1 shows that on average all the changes are positive, which means that the assets, the three deposits and cost of funds always increase every month for the ten banks during the six years. To test whether they are really positive, they are tested by one-sample t-test and Table 4.2 shows the result. 
Indications of ...

Table 4.2 The result for One Sample t-test

\begin{tabular}{|c|c|c|c|c|c|c|c|c|c|}
\hline \multicolumn{10}{|c|}{ Changes from November to December } \\
\hline \multicolumn{10}{|c|}{ Test Value $=0$} \\
\hline $\begin{array}{c}\text { Big Five } \\
\text { Banks }\end{array}$ & $\mathbf{T}$ & Df & $\begin{array}{l}\text { Sig. (2- } \\
\text { tailed) }\end{array}$ & $\begin{array}{l}\text { Sig. } \\
\text { (one- } \\
\text { tailed) }\end{array}$ & $\begin{array}{c}\text { Bank not } \\
\text { in Top } \\
\text { Ten List }\end{array}$ & $\mathbf{T}$ & Df & $\begin{array}{l}\text { Sig. (2- } \\
\text { tailed) }\end{array}$ & $\begin{array}{l}\text { Sig. } \\
\text { (one- } \\
\text { tailed) }\end{array}$ \\
\hline $\begin{array}{l}\text { Asset } \\
\text { changes }\end{array}$ & 6,019 & 29 & 0,000 & 0,000 & $\begin{array}{l}\text { Asset } \\
\text { changes }\end{array}$ & 2,967 & 29 & 0,006 & 0,003 \\
\hline $\begin{array}{c}\text { DD } \\
\text { Changes }\end{array}$ & 3,619 & 29 & 0,001 & 0,0005 & $\begin{array}{l}\text { Demand } \\
\text { deposit } \\
\text { Changes }\end{array}$ & $-1,052$ & 29 & 0,301 & 0,1505 \\
\hline $\begin{array}{c}\text { SD } \\
\text { Changes }\end{array}$ & 7,521 & 29 & 0,000 & 0,000 & $\begin{array}{l}\text { Saving } \\
\text { Changes }\end{array}$ & 5,019 & 29 & 0,000 & 0,000 \\
\hline $\begin{array}{c}\text { TD } \\
\text { changes }\end{array}$ & 3,766 & 29 & 0,001 & 0,0005 & $\begin{array}{l}\text { Deposit } \\
\text { changes }\end{array}$ & 0,995 & 29 & 0,328 & 0,164 \\
\hline $\begin{array}{c}\text { DPK } \\
\text { chages }\end{array}$ & 5,730 & 29 & 0,000 & 0,000 & $\begin{array}{l}\text { Customer } \\
\text { fund } \\
\text { chages }\end{array}$ & 1,547 & 29 & 0,133 & 0,0665 \\
\hline $\begin{array}{l}\text { COF } \\
\text { changes }\end{array}$ & 2,636 & 29 & 0,013 & 0,0065 & $\begin{array}{l}\text { COF } \\
\text { changes }\end{array}$ & 3,329 & 29 & 0,002 & 0,001 \\
\hline \multicolumn{10}{|c|}{ Average Changes Before November } \\
\hline \multicolumn{10}{|c|}{ Test Value $=0$} \\
\hline $\begin{array}{c}\text { Big Five } \\
\text { Bank }\end{array}$ & $\mathbf{T}$ & Df & $\begin{array}{l}\text { Sig. (2- } \\
\text { tailed) }\end{array}$ & $\begin{array}{l}\text { Sig. } \\
\text { (one- } \\
\text { tailed) }\end{array}$ & $\begin{array}{l}\text { Banks } \\
\text { not in } \\
\text { Top Ten } \\
\text { List }\end{array}$ & $\mathbf{T}$ & Df & $\begin{array}{l}\text { Sig. (2- } \\
\text { tailed) }\end{array}$ & $\begin{array}{l}\text { Sig. } \\
\text { (one- } \\
\text { tailed) }\end{array}$ \\
\hline $\begin{array}{l}\text { Asset } \\
\text { changes }\end{array}$ & 4,178 & 29 & 0,000 & 0,000 & $\begin{array}{l}\text { Asset } \\
\text { changes }\end{array}$ & 4,428 & 29 & 0,000 & 0,000 \\
\hline $\begin{array}{c}\text { DD } \\
\text { Changes }\end{array}$ & 3,151 & 29 & 0,004 & 0,002 & $\begin{array}{l}\text { Demand } \\
\text { deposit } \\
\text { Changes }\end{array}$ & 2,537 & 29 & 0,017 & 0,0085 \\
\hline $\begin{array}{c}\text { SD } \\
\text { Changes }\end{array}$ & 7,732 & 29 & 0,000 & 0,000 & $\begin{array}{l}\text { Saving } \\
\text { Changes }\end{array}$ & 4,374 & 29 & 0,000 & 0,000 \\
\hline $\begin{array}{c}\text { TD } \\
\text { changes }\end{array}$ & 4,406 & 29 & 0,000 & 0,000 & $\begin{array}{c}\text { Deposit } \\
\text { changes }\end{array}$ & 1,791 & 29 & 0,084 & 0,042 \\
\hline $\begin{array}{c}\text { DPK } \\
\text { chages }\end{array}$ & 8,557 & 29 & 0,000 & 0,000 & $\begin{array}{l}\text { Customer } \\
\text { fund } \\
\text { chages }\end{array}$ & 4,778 & 29 & 0,000 & 0,000 \\
\hline $\begin{array}{c}\text { COF } \\
\text { changes }\end{array}$ & 15,066 & 29 & 0,000 & 0,000 & $\begin{array}{l}\text { COF } \\
\text { changes }\end{array}$ & 16,298 & 29 & 0,000 & 0,000 \\
\hline
\end{tabular}

Source: Processed secondary data 
The lower part of Tabel 4.2 shows that all changes are positive, at significance level of under $5 \%$, whether the banks are in the top ten lists or not. It means that for the eleven months, the assets, the three deposits and cost of funds of the ten banks are always increasing over the six-year period. If the ten banks can represent the whole banks, it means that the Indonesian banking industry were in growing periode during 2006 to 2011 , so that the assets, deposits, as well as the cost of funds were increasing every month.

The upper part of Table 4.2 shows that there are some differences between the big five banks and the banks not in the top ten list. The assets changes are positives significant both for the big five banks as well as for those not in the top ten lists. It means that the positive growth of assets take place in the two groups of banks. Again, it shows that the whole banks are growing.

The demand deposits (DD) and time deposits (TD) changes are positive for the big five banks at $5 \%$ significance level, but they do not happen to the non big ten banks (it is only significance $15 \%$ and $16 \%$ level). The explanation is that it may be because the demand deposits and time deposits are used by the big five banks to increase the assets temporarily. Demand deposits and time deposits are usually bulky funds owned by corporations or rich individuals so that it may be possible for the big five banks to gather quick funds in a short time during the year ends.

Meanwhile, the saving deposits changes are positive significance at $5 \%$ level both for the big five banks as well as for the non big ten banks. It may because the saving deposits are not used by the big five banks to increase the assets temporarily at the year ends. Usually, saving deposits are individual accounts with small ballances, so that it will be so difficult to gather big funds from millions of small customers in a very short time, that is in one month at the year ends.

\subsection{Inferential Analysis}

\subsection{1 $\mathrm{H}_{1}, \mathrm{H}_{2}$, and $\mathrm{H}_{3}$ Test}

Independent samples t test is used to answer $\mathrm{H} 1, \mathrm{H} 2$, and $\mathrm{H} 3$ proposed previously by comparing means from two independent samples assumed normally distributed. In this case, tested variables are assets, customer deposits (DPK), demand deposits (DD), saving deposits (SD), time deposits (TD), and cost of fund (COF). Two-sided or two-tailed test will be applied, and the general pattern of the hypothesis testing is as follows:

where:

\section{$H_{0:} \mu_{1} \leq \mu_{2}$ dan $H_{a:} \mu_{1}>\mu_{2}$}

$\mu_{1}=$ Average increment of assets, D PK, DD, SD, TD, and COF at the year ends (from November to December).

$\mu 2=$ Average of monthly increment of assets, DPK, DD, SD, TD, and COF for the eleven months other at the year ends (other than November to December).

$\mathrm{H}_{0}=$ Average increment of assets, DPK, DD, SD, TD, and COF at the year ends are smaller than or equal to the average increment of those varibles for the eleven months other than year ends. 
$\mathrm{Ha}_{\mathrm{a}}=$ Average increment of assets, DPK, DD, SD, TD, and COF at the year ends are higher than the average increment of those varibles for the eleven months other than year ends.

The two-samples-t-tes are tested with equal variances assumed and equal variances not assumed and applied to the big five banks and the non big ten banks.

\subsection{The Result Analysis Inferential}

\subsubsection{The Result test $\mathrm{H}_{1}, \mathrm{H}_{2}$, and $\mathrm{H}_{3}$ for the Big Five Banks}

Table 4.3 shows the result of independent sample $t$ test, to show whether the incremental assets, DPK, DD, SD, TD, and COF in the Blg Five Banks at the year ends are significantly higher than those in the eleven months other than year ends.

Table 4.3 The results of Two Independent Samples t-test on the Big Five Banks

\begin{tabular}{|l|l|r|r|r|r|}
\hline \multicolumn{2}{|c|}{\begin{tabular}{l} 
Big Five Banks \\
\multicolumn{2}{|l|}{}
\end{tabular}} & \multicolumn{1}{c|}{ T } & Df & $\begin{array}{r}\text { Sig. (2- } \\
\text { tailed) }\end{array}$ & $\begin{array}{c}\text { Sig. (one } \\
\text { tailed) }\end{array}$ \\
\hline Increase in & Equal variances assumed & 4,757 & 58 & 0,000 & 0,000 \\
\hline assets & Equal variances not assumed & 4,757 & 33,001 & 0,000 & 0,000 \\
\hline $\begin{array}{l}\text { Increase in } \\
\text { DPK }\end{array}$ & Equal variances assumed & 4,964 & 58 & 0,000 & 0,000 \\
\cline { 2 - 6 } & Equal variances not assumed & 4,964 & 29,442 & 0,000 & 0,000 \\
\hline $\begin{array}{l}\text { Increase in } \\
\text { DD }\end{array}$ & Equal variances assumed & 3,363 & 58 & 0,001 & 0,0005 \\
\cline { 2 - 6 } & Equal variances not assumed & 3,363 & 29,353 & 0,002 & 0,001 \\
\hline $\begin{array}{l}\text { Increase in } \\
\text { SD }\end{array}$ & Equal variances assumed & 6,407 & 58 & 0,000 & 0,000 \\
\cline { 2 - 6 } & Equal variances not assumed & 6,407 & 30,08 & 0,000 & 0,000 \\
\hline $\begin{array}{l}\text { Increase in } \\
\text { TD }\end{array}$ & Equal variances assumed & 2,896 & 58 & 0,005 & 0,0025 \\
\cline { 2 - 6 } & Equal variances not assumed & 2,896 & 31,006 & 0,007 & 0,0035 \\
\hline $\begin{array}{l}\text { Increase in } \\
\text { COF }\end{array}$ & Equal variances assumed & 4,825 & 58 & 0,000 & 0,000 \\
\cline { 2 - 6 } & Equal variances not assumed & 4,825 & 44,527 & 0,000 & 0,000 \\
\hline
\end{tabular}

Source: Secondary Data that have been processed

The result in Table 4.3 above shows that $H_{0}$ is rejected at significant level less than $1 \%$ for all variables of the Big Five Banks, both for equal variance assumed as well as not assumed. This may indicate that in the Big Five Banks do the special efforts to increase assets, DPK, DD, SD, TD, and COF at the year ends.

\subsection{2 $\mathrm{H}_{4}$ Test Results}

\section{Test results of $\mathrm{H}_{4}$ on the big five banks and Non Big Ten Banks}

As explained above, $\mathrm{H}_{4}$ is to show the reversal down of assets at the begining of the next years, afters it is temporarily pushed up at the last year end. Table 4.5 shows the results for tests the Five Big Banks as well as the Non Big ten Banks. 
Tabel 4.5 Down of Assets from December to January

\begin{tabular}{|c|c|c|c|c|c|c|c|c|c|}
\hline \multicolumn{10}{|c|}{ Change from december $n$ to january $n+1$} \\
\hline \multicolumn{10}{|c|}{ Test Value $=0$} \\
\hline $\begin{array}{l}\text { Big five } \\
\text { Banks }\end{array}$ & $\mathbf{T}$ & Df & $\begin{array}{l}\text { Sig. (2- } \\
\text { tailed) }\end{array}$ & $\begin{array}{l}\text { Sig. } \\
\text { (one- } \\
\text { tailed) }\end{array}$ & $\begin{array}{c}\text { Bank } \\
\text { Instead big } \\
\text { ten }\end{array}$ & $T$ & Df & $\begin{array}{l}\text { Sig. (2- } \\
\text { tailed) }\end{array}$ & $\begin{array}{l}\text { Sig. } \\
\text { (one- } \\
\text { tailed) }\end{array}$ \\
\hline $\begin{array}{l}\text { Change of } \\
\text { assets }\end{array}$ & $-1,647$ & 24 & 0,112 & 0,056 & $\begin{array}{l}\text { Change of } \\
\text { assets }\end{array}$ & 0,511 & 24 & 0,614 & 0,307 \\
\hline $\begin{array}{l}\text { Change of } \\
\text { DD }\end{array}$ & $-2,926$ & 24 & 0,007 & 0,0035 & $\begin{array}{l}\text { Change of } \\
\text { demand } \\
\text { Deposit }\end{array}$ & 1,371 & 24 & 0,183 & 0,0915 \\
\hline $\begin{array}{l}\text { Change of } \\
\text { SD }\end{array}$ & $-4,134$ & 24 & 0,000 & 0,000 & $\begin{array}{l}\text { Change of } \\
\text { saving account }\end{array}$ & $-0,92$ & 24 & 0,367 & 0,1835 \\
\hline $\begin{array}{l}\text { Change of } \\
\text { TD }\end{array}$ & $-3,009$ & 24 & 0,006 & 0,003 & $\begin{array}{l}\text { Change of } \\
\text { Deposits }\end{array}$ & $-0,549$ & 24 & 0,588 & 0,294 \\
\hline $\begin{array}{l}\text { Change of } \\
\text { DPK }\end{array}$ & $-4,181$ & 24 & 0,000 & 0,000 & $\begin{array}{l}\text { Change of } \\
\text { Costumer } \\
\text { Fund }\end{array}$ & 0,166 & 24 & 0,87 & 0,435 \\
\hline
\end{tabular}

Table 4.5 above shows that negative change or down of assets significantly happened in the Big Five Banks while the change did not happen in the Non Big Ten Banks. This shows that in the Big Five Banks the reversal of all variables takes place at the begining of next years after temporarily increased at the previous year ends, while those phenomenas do not happen in the Non Big Ten Banks.

\section{CONCLUSION}

This research shows the existence of indications of window dressing practices in the Big Five Banks through temporarly increasing their assets at the year ends. The temporary increase in assets may be funded by increasing customer funds of demand and time deposits and not saving deposits. There is also temporay increase in the year end cost of funds in the Big Five Banks as though they are ready to pay more to achieve the assets increase. Those indications can be shown only in the Big Five Banks and not in the Non Big Ten Banks as though only the Big Five Banks have the motivation to dress their windows. 


\section{REFERENCE}

Allan. A, and A. Saunders, "Bank Window Dressing: Theory and Evidence," Journal of Banking and Finance 16 (1992) 583-623.

Ali, Masyhud. (2004). Asset Liability Management. "Menyiasati Resiko Pasar dan Resiko Operasional dalam Perbankan." Jakarta: PT Alex Media Komputindo.

Griffiths, M. D. and D. B. Winters. (2005). "The Turn of the Year in Money Markets: Tests of the Risk-shifting Window Dressing and Preferred Habitat Hypotheses," Journal of Business 78 (4), 1337 - 1363.

Jones, J., "Earnings Management During Import Relief Investigations" Journal of Accounting Research (Autumn, 1991) 193-228.

Kotomin, V. and D. B. Winters. (2006). "Quarter-end Effects in Banks: Preferred Habitat or Window Dressing." Journal of Financial Services Research 29 (1), 61 - 82.

Mian, S.L. and C.W. Smith, JR, "Incentives for Unconsolidated Financial Reporting," Journal of Accounting and Economic (January, 1990), 141-171.

Megasari, Dyah. "BI rilis peringkat 10 besar bank umum dari sisi aset dan pangsa pasar."

Kontan 14 Februari 2011. 14 Februari 2011. http://keuangan.kontan.co.id/news/bi-rilisperingkat-10-besar-bank-umum-dari-sisi-aset-dan-pangsa-pasar.

Scott, William R. (2003). Financial Accounting Theory (Third Edition). University of Waterloo.

Siamat, Dahlan. (2005). Manajemen Lembaga Keuangan. "Kebijakan Moneter dan Perbankan", Jakarta: Fakultas Ekonomi Universitas Indonesia, edisi kesatu.

Yang, Shanshan. And Sherrill Shaffer. (2009). "Bank Window Dressing: A Re-Assessment and a Puzzle." CAMA Working Paper No. 6/2010.

http://www.bi.go.id/web/id/Perbankan/lkhtisar+Perbankan/Lembaga+Perbankan/ 